\title{
ACCESS TO ORPHAN DRUGS: A CROSS COUNTRY COMPARISON OF LEGISLATIVE APPROACH AMONG SERBIA, CROATIA AND MACEDONIA
}

\author{
Dušanka Krajnović1, Jasmina Arsić2 , Ljiljana Tasić1, \\ Guenka Petrova ${ }^{3}$, Svetlana Milijić ${ }^{4}$
}

\begin{abstract}
Access to orphan drugs (In EU regulation Orphan Drugs are refered as Orphan Medicinal Products (OMP)) is a key role in determining whether patients with rare diseases (RDs) will receive adequate and efficient treatment. The objective of this article is to identify differences in patient access to orphan drugs in 3 pharmaceutical markets: Serbia, Croatia and Macedonia. Patient access was defined: as the market access (availability) and affordability (financial accessibility). We analysed the legislative requirements for the authorisation process and made a cross country comparison. Retrospective cross-sectional analysis was done on drug lists in selected countries and a cross-comparison between the List of Orphan Drugs in Europe (LODE) for a six-month period (May 2014-October 2014). We included all 179 OMPs marketed in EU in our analysis, which had received market authorization in Croatia upon its membership in the EU. Total number of marketed drugs in Serbia was 59 (32.96\%) drugs and in Macedonia 52 $(29.05 \%)$ drugs. However, market authorization does not guarantee patient access to any given drug, so only $39.11 \%$ of OMPs could be accessed by Croatian patients (70 drugs).The number of refunded drugs in Serbia and Macedonia was smaller (32 and 20, respectively) which makes respectively, $17.88 \%$ and $11.17 \%$ of drugs on the LODE. The present study showed some variations between countries in selected indicators of availability and access to orphan drugs. Patients in Croatia had greater number of registered and refunded drugs, but in Serbia more than a half of registered OMPs could be refunded from National Health Insurance Fund. Macedonia had smaller number of inhabitants and also had the smaller number of patients from certain RDs which results in lower total number of OMPs.
\end{abstract}

Acta Medica Medianae 2018;57(4):43-51.

Key words: orphan medicinal product (OMP), affordability, availability, rare diseases, legislative requirements

\footnotetext{
${ }^{1}$ University of Belgrade, Faculty of Pharmacy, Department of Social Pharmacy and Pharmaceutical Legislation, Belgrade, Serbia,

${ }^{2}$ At the time of the research student at postgraduates specialization programme, University of Belgrade, Faculty of Pharmacy, Department of Social Pharmacy and Pharmaceutical Legislation, Belgrade, Serbia

${ }^{3}$ Medical University of Sofia, Faculty of Pharmacy, Department of Social Pharmacy, Sofia, Bulgaria

${ }^{4}$ Republic Fund for Health Insurance, Niš, Serbia
}

Contact: Dušanka Krajnović

Faculty of Pharmacy

450 Vojvode Stepe Str, 11221 Belgrade, Serbia

E-mail: parojcic@pharmacy.bg.ac.rs dusica.krajnovic@pharmacy.bg.ac.rs

\section{Introduction}

According to the Regulation on Orphan Medicinal Products of the European Parliament and the European Council (EC) $N^{\circ} 141 / 2000$ Orphan Medicinal
Products (OMPs, also known as Orphan drugs-ODs ${ }^{1}$ ) are used for the diagnosis, treatment and prevention of rare diseases (RDs) occurring with a prevalence of at least $0.05 \%$, i.e. affecting no more than 5 in 10,000 people (1). In Europe, the status of rare diseases may refer to all diseases without a specific treatment while in the USA, regardless of their prevalence, rare diseases include those without a proven efficient treatment with existing drugs. In both regions of the world, a two-step licensing system is applied by regulatory bodies to market drugs including orphan designation (OD) and marketing authorisation (MA) for an OMP. RD are characterised not only by their low prevalence but also by the fact that the rarity concept can be considered from several aspects (2): the perspective of the centre of expertise (clinical centres of excellence), a diagnostic reference centre, clinical studies, as shown in Figure 1.

${ }^{1}$ We shall use interchangeable the terms Orphan Medicinal Products (OMPs) and orphan drugs (ODs) in this text. 




Figure 1. Rarity concept

The process of obtaining OD includes the centralized procedure of the EU or national procedures for countries that are not EU members. There is a special Committee for Orphan Medicinal Products (COMP) within EMA whose task is to control criteria connected to the significant benefit for acquiring orphan status and to the guidelines for clinical research in small groups which are used for assessment of clinical proof, while acquiring permission (3).

Besides classical drugs for rare diseases which passed the complete procedure for getting the OD and marketing authorisation (MA) EMA recognises additional group of OMPs, without OD and with MA. This group of drugs includes all those drugs which possess drug permission for use with one or more indications for rare diseases, but did not pass the procedure for acquiring OD, or the status was removed. OMPs with MA and without OD cannot be of the same name like the name dedicated to other indications.

\section{Aim}

This paper aimed to evaluate the market access (availability) to OMPs and make a comparison in three neighbouring countries (Serbia, Macedonia and Croatia) with regulatory approach. A further aim was tto evaluate affordability (financial accessibility) of OMP in selected coutries.

\section{Material and methods}

The following methods were used: a comparative analysis of applications for MA of drugs in Serbia, Macedonia, and Croatia. Serbia and Macedonia are non-Eu countries and Croatia is EU country with EU/EMA procedures accepted. The manual document analysis of secondary data was conducted on October 2014, comparing the national legislative files with the Regulation on OMP (Regulation (EC) no. $141 / 2000$. Furthermore, in order to study potential differences between OMP availability and afford- ability in Serbia, Macedonia and Croatia, we performed a comparative study of the authorised OMP and OMP included in the reimbursement drug lists in the selected countries.

First, we obtained information about the OMPs with MA in Europe from the List of Orphan Drugs in EU (LODE) for a six-month period (May 2014-October 2014), including OMP with and without prior OD (4). Then, we searched the officially issued sources for authorised drugs and reimbursed drugs in the three countries. Information on the OMP availability in these countries was systematized by INN and ATC code from the databases of the national authorities for National drug registers (NDRs) and National Reimbursement Lists (NRLs). The market access of OMPs was analyzed by crossing OMPs identified in the NDRs and LODE; the affordability was evaluated by crossing NRLs with LODE among the three countries.

The data were collected from the NDRs in Serbia, Macedonia and Croatia. The data of reimbursed OMP were collected from the NRLs in selected countries.

The sources of documents were collected from the official website of the Medicines and Medical Devices Agency of Serbia (MMDAS) and from the National Health Insurance Fund (NHIF) of the Republic of Serbia $(5,6)$, from the official website of the Ministry of Health, and NHIF of the Republic of Macedonia (7) and from the official website of the Medicines and Medical Devices Agency of Croatia (MMDAC) and NHIF of Croatia $(8,9)$.

\section{Results}

The results connected with the regulatory availability refer to the analysis of legislative approaches for the acquiring and renewal of the $M A$, in the sense of time limits for procedures and types of MA procedures. The availability analysis refers to the registered drugs authorised at national drug lists, while the analysis refers to reimbursed drugs, meaning 
financial affordability of the drugs in the selected countries. All the results are given for each country as follows (Serbia, Macedonia and Croatia) and then the comparison between them was made.

Analysis of the legislative and policies to OMP in the selected countries

All three selected countries define similar regulatory requirements for the MA of OMP. The analysis of the application for MA will be presented in the following sections whereas the comparison of the results obtained in the selected countries is presented in Table 1.

\section{Serbia - regulatory approach}

According to the National Organization for Rare Diseases of Serbia (NORDS), about 500.000 people are suffering from some of the RD out of 7.2 million of inhabitants in Serbia (10). In the Republic of Serbia, the MA of OMP is included in the national procedure for MA of all medicinal products. A drug is launched onto the market with a predetermined intensity of effect, pharmaceutical form and package based on a drug licence issued by the MMDAS which confirms that all the regulatory requirements for MA have been fulfilled and that a drug fulfils the standards of high quality, safety and efficiency. Moreover, the latest amendments introduced by the pharmaceutical legislature in the Republic of Serbia in 2010, taken over from the European directives on medicines, pertain directly and indirectly to OMPs: i) a new definition of drugs was introduced so as to include all the progressive forms of therapy, gene or cell therapy, ii) the drug licence is to be renewed after five years after which period it is issued for an indefinite period of time, iii) a new period for data protection related to the results of pre-clinical and clinical studies, the so called " $8+2+1$ " period (data exclusivity period), was introduced by a new directive, iv) the introduction of new categories for drug marketing authorisation and licensing accelerated approval licence is to be granted within 150 days after receiving the complete application (Table 1 .). A conditional approval may be granted for drugs used for the treatment, prevention or diagnosis of RDs and for drugs already licensed under a centralised procedure as well as other drugs of great importance for public health. Upon agreement with an applicant, MMDAS may issue a drug licence under certain conditions, which the applicant is expected to fulfil and which are revised and checked by MMDAS once in 12 months following the date the adaptive licence was issued. The licence is valid for 12 months and may be renewed until the necessary requirements for a proper licence are fulfilled in case the benefits of the drug in question surpass the risks that may occur due to insufficient data on a clinical research. An adaptive licence may be issued under an accelerated procedure.

\section{Macedonia - regulatory approach}

It is estimated that in Macedonia from 2.1 million people, there are about 100.000 patients suffering from RDs. The Macedonian Law on Medicines and Medical Devices governs the use of medicines and medical devices in human medicine, their quality, safety and effectiveness, their production, testing, marketing, sale, prices, quality control, advertising and inspection supervision (11). The Medicines and Medical Devices Agency of Macedonia (MMDAM) issues approvals for drugs authorised in at least three EU countries within 15 days after a complete application was submitted on the basis of their quality, safety and effectiveness estimated in the procedure of MA in the EU and upon the proposal of the Committee for Medicines. In case of submitting an application for a drug authorised in fewer than three EU countries, the MMDAM either accepts or rejects the application within 90 days after the application was submitted on the basis of the drug's quality, safety and effectiveness estimated in the MA in the EU and upon the proposal of the Committee for Medicines. $\mathrm{MA}$ is granted for a period of eight years.

An adaptive licence is granted by the Agency in case the drug in question is unavailable, yet essential for a patient's welfare and treatment (rare diseases, ethical aspects, life-threatening diseases). An adaptive licence is granted for one year at most (12).

\section{Croatia - regulatory approach}

It is estimated that in Croatia there are about 250.000 patients suffering from RDs (4.2 million populations) The Republic of Croatia placed OMPs on the "List of exceptionally expensive drugs" in 2006. OMPs include all drugs that pursuant to regulations in the European Union have been granted the status of drugs used for the treatment of serious and rare diseases. Since 2010, Medicines and Medical Devices of Croatia (MMDAC) has been publicising a list of OMPs with MA and OD in the EU and which have been granted a European marketing authorisation (EMA) (13). In accordance with the Law on Medicines, OMP include all drugs that pursuant to EU regulations have been granted the status of drugs used for the treatment of serious and rare diseases (13). Since 2010, the MMDAC has been posting on its Internet pages a list of OMPs with an OD in the EU and MA (13). The Managing Board of the Croatian Health Insurance Fund determines which drug is to be placed on the "List of exceptionally expensive drugs" after deliberation by the Committee for Medicines. The financing of treatment by a drug from the "List of expensive drugs" is financed by a separate fund part of the state budget allocated to expensive drugs under supervision paying particular attention to the control of drugs use increase. Compassionate use of drugs is also possible from the moment of diagnosis until the drug is authorised for use. OMPs 
availability depends on import procedures and treatment financing. Drugs which are not on the "List of expensive drugs" are financed by hospital funds, which might impose a significant financial burden upon an institution. Table 1 shows legislation and policies in the area of rare diseases and orphan drugs in Serbia, Macedonia and Croatia.

Table 1. Legislation and policy in the area of rare diseases and orphan drugs in Serbia, Macedonia and Croatia

\begin{tabular}{|c|c|c|c|}
\hline & Serbia & Macedonia & Croatia \\
\hline Population (mill) & 7.2 & 2.11 & 4.3 \\
\hline GDP per capita in 2014 (Euro) & 3772 & 2642 & 9620 \\
\hline $\begin{array}{l}\text { Number of patients with rare } \\
\text { diseases }\end{array}$ & 500.000 & 100.000 & 250.000 \\
\hline \multicolumn{4}{|c|}{ Key incentives of the orphan drug legislation } \\
\hline $\begin{array}{l}\text { The time limit for the valid } \\
\text { application for MA (days) }\end{array}$ & 210 & 210 & 210 \\
\hline $\begin{array}{l}\text { The time limit for the reduced } \\
\text { application for MA (days) }\end{array}$ & 150 & $\begin{array}{l}15 \text { days if MP is avaliable in } 3 \\
\text { countries in EU } \\
90 \text { days if MP is avaliable in }<3 \\
\text { countries in EU }\end{array}$ & 150 \\
\hline $\begin{array}{l}\text { Orphan Drug MA (years) } \\
\text { Normal approvals }\end{array}$ & 5 & 5 & 5 \\
\hline $\begin{array}{l}\text { Orphan Drug MA (years) } \\
\text { Conditional approvals }\end{array}$ & 1 & 1 & 1 \\
\hline $\begin{array}{l}\text { Orphan Drug MA (years) } \\
\text { Exeptional circumstances }\end{array}$ & / & / & 1 \\
\hline
\end{tabular}

Analysis of market access of OMPs in the selected countries

In October 2014, 78 orphan drugs were on the LODE in Europe with OD and with MA in the EU and 101 drugs with MA and without OD (14).
In Serbia, $32.96 \%$ of OMPs were on the LODE, while $29.05 \%$ of all drugs in Macedonia were on the LODE (Graph 1.). All 179 registered drugs on the LODE became available in the Republic of Croatia upon its membership in the EU (October 2014).

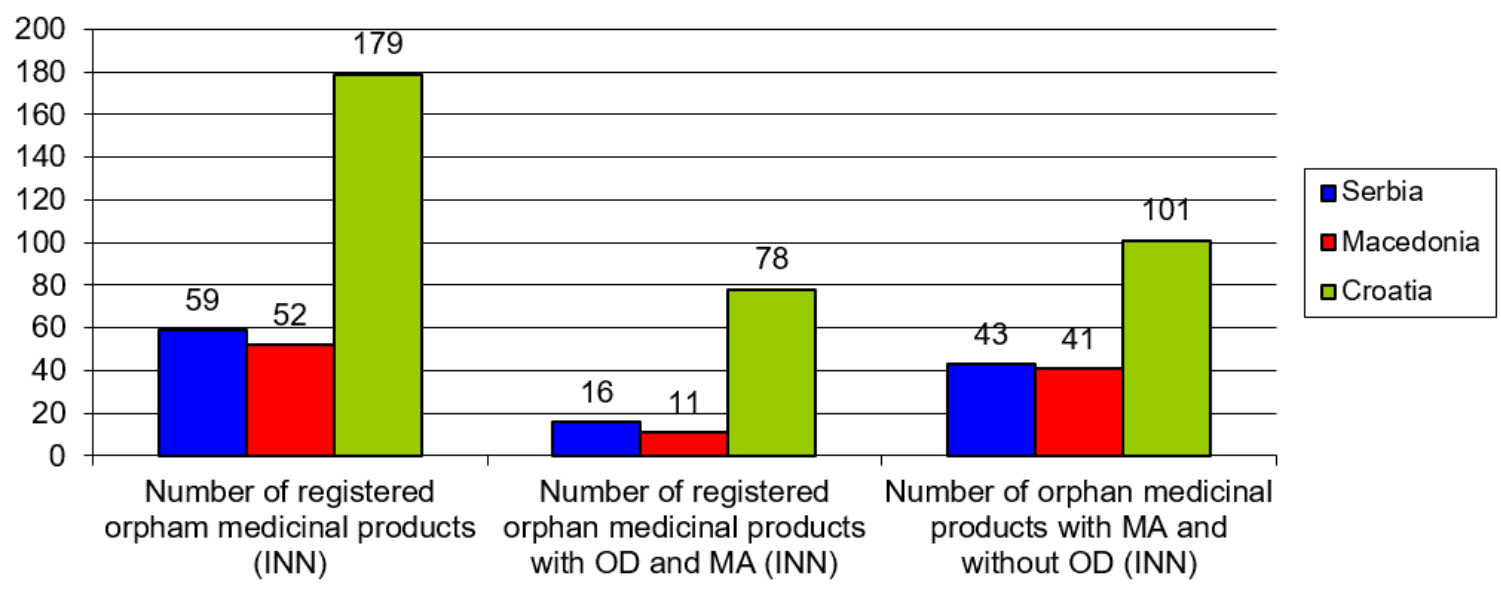

Graph 1. Total number of OMPs in the selected countries (October 2014) 


\section{Analysis of affordability of OMPs in the selected countries}

\section{Serbia - affordability}

The amendments to the Law on health insurance created legal grounds for providing distinct funds in the Serbian budget for financing the treatment of RD (15). The financial plans for patients were first drafted in 2012 on which occasion a separate fund was established. The fund is supposed to finance medical expenses caused by the treatment of RD with drugs not included in the NRLs. The financing of the fund is regulated by the Law of Health Insurance and the Law of Games of Chance so that 5\% of the budget income is allocated to financing treatment of RD $(15,16)$. An amount of 335,322000 RSD (corresponding to about 2,733,781 EUR) was anticipated by the amendments to the financial plan for year 2014 to be transferred to the National Fund from the budget of Serbia intended for health protection and treatment RD patients (17). In Serbia, OMPs are on one of the five Lists of drugs of the National Health Insurance Fund of the Republic of Serbia (NHIFRS) (A, A1, B, C, D) and are subject to either complete or partial reimbursement. The Government of Serbia, on the $30^{\text {th }}$ August 2014, founded the Budget fund for treatment and conditions or injures that could not be successfully treated in Serbia. The Fund is intended for the treatment of children up to 18 years suffering from RDs that are curable abroad if it is not possible to diagnose them in Serbia. The Fund is open in an indefinite period and managed by the Ministry of Health (18).

\section{Macedonia - affordability}

In Macedonia, OMPs are financed by funds from the budget of Macedonia. At the beginning of every year, the Government adopts the Programme for the treatment of RDs in the Macedonia defining how much money from that year's budget is allocated to this purpose and how it will be spent (19). The government of Macedonia adopts the Programme for the treatment of RDs pursuant to the Law of Health Insurance every year. In 2014, the Programme was financed with 80,000,000 MKD (corresponding to about $1,331,412$ EUR). The newest amendments to the Law of Excise and the Law of Health Insurance adopted in December 2014 determined that an amount of 0053 MKD per cigarette pack was to be used for the financing of rare diseases, which is an extra amount of 250,000,000 MKD annually (corresponding to about 4,160,662 EUR). OMPs are purchased through the Ministry of Health in government procurement. In Macedonia, there is only one NRLs without any fees imposed on the patients. Unregistered drugs may be purchased on condition there is no other adequate therapy for certain patients and that these drugs have already been submitted to the licensing procedure or have been included in clinical research.

\section{Croatia - affordability}

The Croatian Law on Medicines is congruent to EU directives. The integral list of drugs for rare and serious diseases is being modulated and harmonised with the EU list. Medical expenses for the treatment of rare diseases are reimbursed by the state. The Croatian Ministry of Health is entitled to start an OD procedure. The national programme for RD predicted an amount of 360,689,000 HRK $(47,155,052$ EUR) to be spent for their treatment for the period from 2015 to 2020 (20).

The representation of drugs which are being on NRLs relative to the complete number of registered OMPs in selected countries shows that in Serbia more than a half of drugs is financially affordable comparing with Macedonia and Croatia where the financially affordable drugs make a third of complete registered OMP (Graph 2.).



Graph 2. Total number of reimbursed OMPs (October 2014) 
The financially most affordable OMPs with OD and MA, according to the first level of ATC classification were in group $L$ - antineoplastics in all researched countries (Graph 3.).
The financially most affordable OMPs without OD and MA according to the first level of ATC classification were in group $L$ - antineoplastics, in all studied countries (Graph 4.).



Graph 3. Number of reimbursed OMPs with OD and MA by ATC code (October 2014)

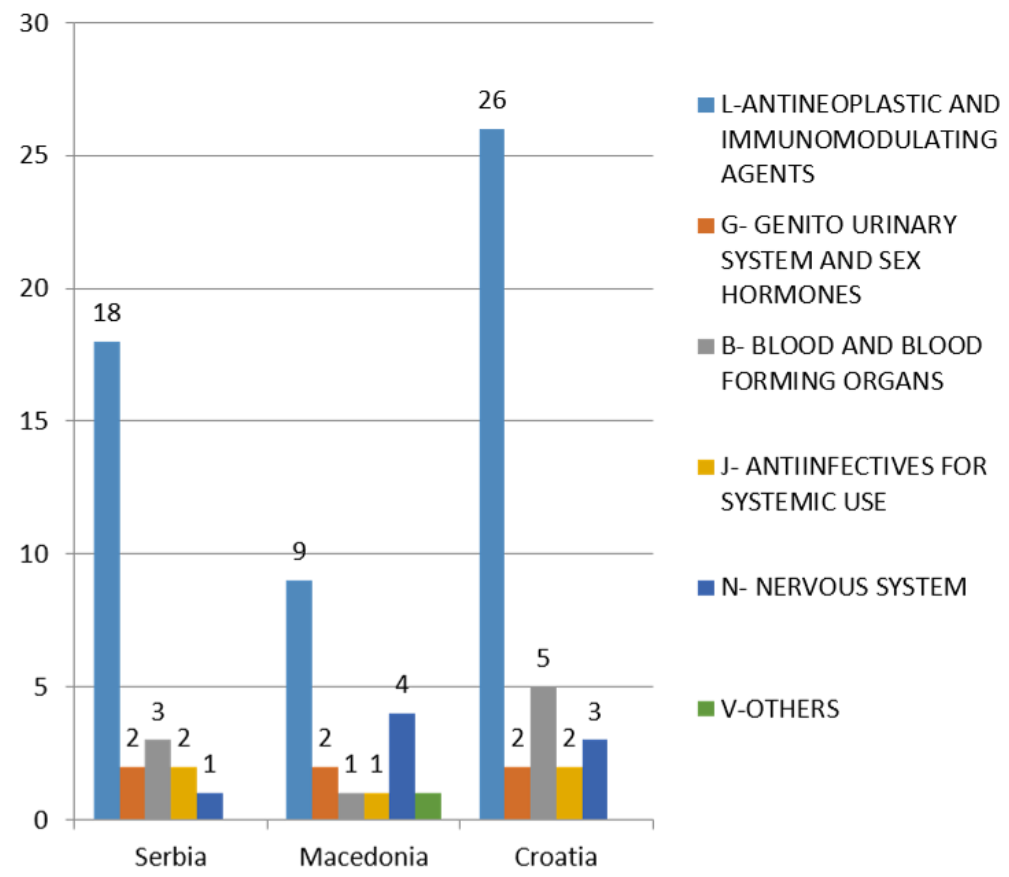

Graph 4. Number of reimbursed OMPs with MA and without OD by ATC code (October 2014) 


\section{Discussion}

The mutual comparison of the financially affordable OMPs in Serbia, Macedonia and Croatia comparing with the complete number of registered drugs of this category represents the biggest financial affordability of these drugs is in Serbia (54.24\% of registered drugs), while it is smaller in Macedonia and Croatia (38.46\%, 39.10\% respectively), no matter that Macedonia has the smallest number of registered drugs from the LODE while Croatia has all drugs from the LODE. This indicates to the fact that although there is the problem with the lack of funds for financing the treatment of patients with RD, more than a half of registered OMPs can be refunded from NHIF. Despite the fact that in Croatia, a member of the EU, a greater number of OMPs are registered, they are not completely affordable to the patients. Macedonia has the smallest number of inhabitants out of the three studied countries, which means that it also has the smallest number of patients from certain RD, which results in the lower total number of OMPs that are on the NRLs.There are very similar regulatory approaches in all three studied countries for MA for OMPs because they all came from the same health system and they harmonized the regulations for drugs with the European directive. A couple of authors have been analysing the affordability of OMP in Serbia and other countries (Macedonia, Bulgaria, Greece etc. ) $(21,22)$. Besides, there were studies which compared the affordability of OMPs in other countries of the region, which represented that the affordability of drugs is different and subjected to dynamic changes (23).

The study of Zlatareva et al.(21) have shown the registered OMPs in January 2013 in Serbia, while our study represented the growth of 10 drugs in Serbia till October 2014. Comparing results of Zlatareva study with ours it is shown that the number of refunded drugs ( on the cost of health insurance) is marginally raising so as for the 1 drug with OD and $M A$ and 3 drugs with the MA and without OD.
Pavlovic et al. (22) investigated 4 drugs financially affordable in Serbia with OD and MA and 17 drugs with MA and without OD in July 2011, revealing that the number of affordable drugs is slowly raising in Serbia. Zlatareva et al. represented that there was only one drug with the OD and MA affordable in Macedonia in January 2013 while 14 drugs with the MA and without OD were on the NRLs (21). In 2014, our results suggested that the number of financially affordable drugs in Macedonia raised from one to two drugs with OD and MA, while 18 drugs without OD and MA were on the NRLs.

\section{Conclusion}

From the perspective of health politics, regulative and legislative of OMPs within any country is different, the MA of ODs and the affordability through funds of health insurance is done in many different ways.

Different accessibility of OMPs in all three countries could be explained with the different capacity and modality for financing the treatment of RDs, and national health policies criteria for refunding of these drugs. The affordability and accessibility of OMPs are generally the problem both in developed and undeveloped countries. Our study showed that RD patients in Croatia have better accessibility of drugs than patients in Serbia and Macedonia, but in Serbia the affordability is rather better because half of the registered OMPs is refunded.

\section{Acknowledgement}

The research was conducted within the work of two scientific research projects financed by the Ministry of Education, Science and Technological Development of the Republic of Serbia (project No. 41004 and No. 175036). 


\section{References}

1. European Medicines Agency. Medicines for rare disease. [Internet] [updated-2017 Nov]. Avaliable from: URL:http://www.ema.europa.eu/ema/index.jsp?curl= pages/special topics/general/general content 00003 4.jsp.

2. Pariser AR, Yao LP. Rare Diseases and Orphan Drugs. In: Mulberg $A E$, Murphy $D$, Dunne J, Mathis LL, editors. Pediatric Drug Development. $2^{\text {nd }}$ ed. New York: John Wiley \& Sons Ltd; 2013. P. 130-48. [CrossRef]

3. European Commission. Volume 2A Procedures for marketing authorization Chapter 4 Centralized Procedure. [Internet]. [updated $2017 \mathrm{Nov}$ ]. Available from: URL: http://ec.europa.eu/health/files/eudralex/vol-2/ a/ chap4rev200604 en.pdf.

4. Lists of medicinal products for rare diseases in Europe. [Internet]. [updated 2017 Nov]. Available from: URL: http://www.orpha.net/orphacom/cahiers/docs/GB/list of orphan drugs in europe.pdf.

5. Medicines and Medical Devices Agency of Serbia. Availiable from: URL:

http://www.alims.gov.rs/latin/2014/08/07/nacionalniregistar-lekova-2014/.

6. Serbian institute for health insurance. [Internet]. [updated 2017 Nov]. Available from: URL: http://www.rfzo.rs/index.php/osiguranalica/lekoviinfo/pretraga-liste-lekova.

7. Ministry of Health of the Republic of Macedonia. [Internet]. [updated 2017 Nov]. Available from: URL: http://lekovi.zdravstvo.gov.mk/.

8. Agency for Medicinal Products and Medical Devices of Croatia. [Internet]. [updated 2017 Nov]. Available from: URL:

http://www.halmed.hr/Lijekovi/Informacije-olijekovima/Lijekovi-za-lijecenje-rijetkih-i-teskihbolesti/.

9. Croatian Health Insurance Fund. [Internet]. [updated 2017 Nov]. Available from: URL:

http://www.hzzo.hr/zdravstveni-sustav-rh/trazilicaza-lijekove-s-vazecih-lista/arhiva-liste-lijekova.

10. National Organization for Rare Diseases. [Internet]. [updated 2017 Nov]. Available from: URL: http://www.norbs.rs/o-norbs-u/.

11. Official Gazette of the Republic of Macedonia: Law of drugs and medical devices. No 106, 2007. [Internet]. [updated 2017 Nov]. Available from: URL: https://www.wto.org/english/thewto e/acc e/mkd e/ WTACCMKD24A1 LEG 4.pdf.

12. European Medicines Agency. Orphan designation. [Internet]. [updated 2017 Nov]. Available from: URL: http://www.ema.europa.eu/ema/index.jsp?curl=page s/regulation/general/general content 000029.jsp.

13. Agency for Medicinal Products and Medical Devices of Croatia. [Internet]. [updated 2017 Nov]. Available from:

URL:http://www.halmed.hr/Lijekovi/Informacije-olijekovima/Lijekovi-za-lijecenje-rijetkih-i-teskihbolestil.
14. Orphanet. Lists of medicinal products for rare diseases in Europe. [Internet]. [updated 2017 Nov]. Available from: URL:

http://www.orpha.net/orphacom/cahiers/docs/GB/list of orphan drugs in europe.pdf.

15. Official Gazette of the Republic of Serbia: Law of health insurance. No. 57, 2011. [Internet]. [updated 2017 Nov]. Available from: URL: http://www.skriningsrbija.rs/files/File/English/Republic of Serbia Healthcare Law.pdf.

16. Official Gazette of the Republic of Serbia: Law of Games of chance. No. 88, 2011. [Internet]. [updated 2017 Nov]. Available from: URL: http://www.skriningsrbija.rs/files/File/English/Republic of Serbia Healthcare Law.pdf.

17. Health insurance fund in the Republic of Serbia: The financial plan of the health insurance fund of the Republic of Serbia for the year 2014. [Internet]. [updated 2017 Nov]. Available from: URL: http://www.rfzo.rs/download/finplan2014.pdf.

18. Ministry of Health of the Republic of Serbia. [Internet]. [updated 2017 Nov]. Available from: URL: http://www.zdravlje.gov.rs/showpage.php?id=346.

19. Official Gazette of the Republic of Macedonia: Programme for treating rare diseases in the Republic of Macedonia for the year 2012. No. 8, 2012.

20. Ministry of Health of the Republic of Croatia: Decision on preparing a National orphan drugs programme for the period from 2015 - 2020. [Internet]. [updated 2017 Nov]. Available from: URL: https://zdravlje.gov.hr/UserDocsImages//Programi\%2 0i\%20projekti\%20\%200stali\%20programi//NACIONALNI-PROGRAM-ZARIJETKE-BOLESTI-2015-\%202020.g.\%20(1).docX. [CrossRef][PubMed]

21. Zlatareva A, Lakic D, Kamusheva M, Spaskov D, Momekov G, Petrova G. Analysis of Access to Orphan Drugs in Five Neighboring European Countries Bulgaria, Greece, Macedonia, Romania and Serbia. World Journal of Pharmacy and Pharmaceutical Sciences 2013; 2:4415-34.

22. Pavlović N, Stanimirov $B$, Stojančević $M$, PautKusturica M, Stoimenova A, Goločorbin-Kon S, at al. An insight on differences in availability and reimbursement of orphan medicines among Serbia, Bulgaria and Sweden. Biotechnology \& Biotechnological Equipment 2012, 26(5): 3236-41. [CrossRef]

23. Kamusheva M, Stoimenova A, Doneva M, Zlatareva A, Petrova, G. A Cross Country Comparison of Reimbursed Orphan Medicines in Bulgaria, Greece, Macedonia. Biotechnology and Biotechnology Equipment 2013;27: 4186-93. [CrossRef] 


\title{
DOSTUPNOST LEKOVA ZA RETKE BOLESTI: KOMPARATIVNA ANALIZA LEGISLATIVNIH ZAHTEVA IZMEĐU SRBIJE, HRVATSKE I MAKEDONIJE
}

\author{
Dušanka Krajnović1, Jasmina Arsić ${ }^{2}$, Ljiljana Tasić $^{1}$, \\ Guenka Petrova ${ }^{3}$, Svetlana Milijićt
}

\begin{abstract}
${ }^{1}$ Univerzitet u Beogradu-Farmaceutski fakultet, Katedra za socijalnu farmaciju i farmaceutsko zakonodavstvo, Beograd, Srbija

${ }^{2} \mathrm{U}$ vreme pisanja rada specijalizant na Univerzitetu u Beogradu-Farmaceutskom fakultetu,Katedri za socijalnu farmaciju i farmaceutsko zakonodavstvo, Beograd, Srbija

${ }^{3}$ Medicinski univerzitet u Sofiji, Farmaceutski fakultet, Katedra za socijalnu farmaciju, Sofija, Bugarska

${ }^{4}$ Republički fond za zdravstveno osiguranje, filijala Niš, Niš, Srbija
\end{abstract}

Kontakt: Dušanka Krajnović

Fakultet za farmaciju

Vojvode Stepe 450, 11221 Beograd, Srbija

E-mail: parojcic@pharmacy.bg.ac.rs

dusica.krajnovic@pharmacy.bg.ac.rs

Dostupnost lekova za retke bolesti (orfan lekovi, u EU regulativi koristi se izraz na engleskom Orphan medicinal products, OMP) igra važnu ulogu u tome da li će bolesnici sa retkim bolestima imati pristup efikasnoj i adekvatnoj terapiji. Ciljevi ovog rada su da se identifikuju razlike u pristupu bolesnika orfan lekovima u tri odabrane zemlje: Srbiji, Hrvatskoj i Makedoniji. Pristup orfan lekovima definisana je kao: tržišna pristupačnost (dostupnost) i priuštivost (finansijska pristupačnost). Analizirali smo legislativne zahteve u procesu stavljanja leka u promet i uradili komparaciju među posmatranim zemljama. Retrospektivnom studijom preseka poredili smo nacionalne liste lekova posmatranih zemalja i Listu orfan lekova u EU, za period od šest meseci (maj-oktobar 2014.). Od ukupno 179 OMP, koliko ih je u tom periodu bilo sa dozvolom za stavljanje u promet u EU, u Srbiji je bilo registrovano 59 (32,96\%), u Makedoniji 52 (29,05\%), dok su u Hrvatskoj učlanjenjem u EU svi registrovani lekovi postali tržišno dostupni. Međutim, dozvola za stavljanje u promet nije i garancija da bolesnik ima pristup datom leku, pa je samo $39,11 \%$ lekova sa dozvolom za stavljanje u promet bilo na listi lekova koje se refundiraju u Hrvatskoj (70 OMP). Broj lekova kojima bolesnici imaju pristup preko nacionalnih fondova zdravstvenog osiguranja u Srbiji i Makedoniji su manji (32 OMP i 20OMP, respektivno), što čini da je priuštivost lekova u Srbiji tek $17,88 \%$, a u Makedoniji 11,17\% od liste orfan lekova u EU. Broj lekova, fizička i finansijska pristupačnost u analiziranim zemljama nije ista, dok je u Hrvatskoj bolesnicima dostupan najveći broj registrovanih lekova, u Srbiji se više od polovine registrovanih OMP može refundirati o trošku RFZO. Makedonija zbog manjeg broja stanovnika ima manji broj obolelih od RB, što rezultira manjim brojem OMP.

Acta Medica Medianae 2018;57(4):43-51. zahtevi

Ključne reči: orfan lekovi (OMP), priuštivost, dostupnost, retke bolesti, legislativni 